\title{
Long-term effects of competition on coral growth and sweeper tentacle development
}

\author{
Einat D. Lapid ${ }^{1}$, Nanette E. Chadwick ${ }^{1,2, *}$ \\ ${ }^{1}$ Faculty of Life Sciences, Bar Ilan University, Ramat Gan, Israel, and Interuniversity Institute for Marine Science, Eilat, Israel \\ ${ }^{2}$ Department of Biological Sciences, 101 Rouse Life Sciences Building, Auburn University, Auburn, Alabama 36849, USA
}

\begin{abstract}
Outcomes of competition between corals vary temporally and spatially, and depend in part on the agonistic mechanism involved. Competition may impact coral growth, reproduction and energy reserves, however few experimental studies have quantified these effects. We conducted a 1 yr laboratory experiment on competition between 2 massive corals, Platygyra daedalea and Favites complanata. Colonies of $P$. daedalea developed sweeper tentacles and extensively damaged the $F$. complanata colonies, causing them to loose ca. $55 \%$ of their soft tissue and eventually killing $30 \%$ of F. complanata colonies. Skeletal accretion rate varied widely among corals within each treatment, and correlated negatively with the percent tissue damaged on competing colonies of $F$. complanata. On isolated control colonies, sweeper tentacles developed randomly throughout the year, and then reverted back to feeding tentacles. They appeared to serve as probes to detect the approach of competitors. Development of sweeper tentacles is a powerful aggressive/defensive mechanism that may enable brain corals to dominate some reef areas in the Indo-Pacific region.
\end{abstract}

KEY WORDS: Brain coral $\cdot$ Platygyra $\cdot$ Favites $\cdot$ Red Sea $\cdot$ Eilat $\cdot$ Aggression

\section{INTRODUCTION}

Competition for limited space on marine substrata is an important process influencing the community structure of sessile marine organisms such as reef-building corals (Sebens 1982, Chornesky 1989, Lang \& Chornesky 1990). Impacts of competition on individual coral colonies may include alteration of patterns of reproduction, lipid storage and colony growth (Romano 1990, Ward 1995, Tanner 1997). Outcomes of competition between coral species vary temporally and spatially, and short-term or point observations may lead to false interpretations because reversals can occur in which short-term winner colonies become long-term losers (Bak et al. 1982, Sebens 1982, Chornesky 1989, Romano 1990). Factors influencing the outcome of competition between corals include the angle of encounter (Jackson 1977), colony thickness (Buss 1980), colony shape, physiological condition and season of the year (Sebens 1982).
Competition between corals often results in tissue damage to one or both colonies and involvies necrosis, sloughing of tissues, and eventual exposure of the underlying hard skeleton (Chadwick 1988, Chornesky 1989, Romano 1990, Chadwick-Furman \& Rinkevich 1994, Tanner 1997, Lapid et al. 2004). The mechanisms used by anthozoans to damage competitors include the use of acrorhagi and catch tentacles by actinian sea anemones, and sweeper tentacles and mesenterial filaments by stony corals (Williams 1991). Common to these mechanisms is the deployment of nematocysts to cause damage to opponent tissue. Physical penetration of nematocyst tubules, neurotoxins released by nematocysts, and the shearing action of anchored aggressor tissue all may contribute to damage. In addition, secretion of proteolitic enzymes by extruded mesenterial filaments also can cause necrosis of opponent tissues (Thomason \& Brown 1986, Bigger 1988).

Tissue loss in coral victims does not necessarily cause death of the entire colony but often results in 
partial mortality. The ability of corals to survive following partial loss of tissue and to regenerate lost areas plays a central role in their life history strategies. Tissue regeneration rates of stony corals influence coral reef recovery from environmental disturbances such as chemical pollution and sedimentation, and from biotic interactions such as predation and competition (Yap et al. 1992, Meesters et al. 1996, Cumming 2002). Coral regeneration capacity is highly variable, and depends on the regenerative potential of each species, on intrinsic factors that reduce regeneration capacity over time such as decreases in certain stimuli or resources, lesion type and size, whether the lesion is completely surrounded by tissue or not, and on environmental factors such as levels of water motion. Due in part to their different regeneration abilities, coral species vary in competitive ability (Bak \& Steward-Van Es 1980, Chornesky 1989, Meesters et al. 1996, Rinkevich 1996).

Energetic trade-offs between reproduction, tissue growth and repair in corals are not fully understood. Tissue injuries may create shifts in energy allocation within a single coral colony (reviewed in Rinkevich \& Loya 1989), or alternately in the utilization of circulating stem cells that are available in limited supply (Rinkevich 1996). Between-colony competition likely imposes energetic demands on corals, which in turn cause a trade-off between the allocation of energy to aggressive interactions versus colony growth and reproduction (Tanner 1997).

An important measure of the impact of competition on stony corals is their skeletal growth rate. Techniques to measure linear skeletal increase in stony corals may involve staining with alizarin dye (Lamberts 1974, Guzman \& Cortes 1989, Romano 1990), photography at regular intervals (Chornesky 1989, Tanner 1997), or x-ray radiography and densitometry scanning (Klein \& Loya 1991, Vago et al. 1994). Rates of carbonate accretion in stony corals also may be assessed by recording changes in buoyant weight (Jokiel et al. 1978, Romano 1990). It is not fully clear how physical factors such as depth, season, light level and wave stress influence skeletal accretion in corals, since measurements of coral skeletal growth have not revealed consistent patterns in relation to environmental factors. Some corals such as Pocillopora, Acropora and Pavona do not appear to have seasonal patterns of skeletal growth (Yap et al. 1992), whereas Porites corals have narrow high-density growth bands in winter and wide low-density growth bands during the summer on high latitude reefs (Klein \& Loya 1991). On temperate and subtropical reefs, coral skeletal accretion is fastest during the warmest months, but on tropical reefs it usually is fastest in the winter (Ward 1995). Depth is another factor in dispute; while some studies have recorded no effect of depth on growth rate in Porites corals (Guzman \& Cortes 1989), others have reported faster or slower calcification with depth (Bak \& Steward-Van Es 1980, Oliver et al. 1983, Huston 1985, Davies 1989).

Two studies to date have evaluated the consequences of interspecific competition on stony coral skeletal growth rates (Romano 1990, Tanner 1997). On reefs in the northern Red Sea, corals of the genus Platygyra are competitively dominant over those belonging to the genus Favites in most field interactions (Lapid et al. 2004). Here we describe impacts of long-term competition on skeletal accretion and tissue damage in the brain coral Platygyra daedalea and the massive coral Favites complanata.

\section{MATERIALS AND METHODS}

Twenty small ( 5 to $15 \mathrm{~cm}$ diameter) colonies of each of 2 massive stony coral species, Platygyra daedalea and Favites complanata, were selected haphazardly on artificial substrata by scuba diving at 2 to $6 \mathrm{~m}$ depth near Eilat, northern Red Sea. Small colonies were chosen due to the space constraints of experimental aquaria. The colonies were removed carefully from the substratum using a chisel and hammer, and transported in seawater to the Interuniversity Institute for Marine Science (IUI) at Eilat. They were acclimated for 3 wk in outdoor running seawater tanks at the IUI, then transferred to experimental aquaria at the adjacent Underwater Observatory Marine Park (after Lapid et al. 2004).

Ten colonies of Platygyra daedalea were selected using a random number generator, and each was brought into tentacle contact $(1 \mathrm{~cm}$ apart when tentacles contracted) with a randomly-selected colony of Favites complanata. As a control, 10 colonies of each species were isolated from contact (at least $5 \mathrm{~cm}$ apart when tentacles fully expanded). Treatment and control colonies were interspersed randomly among 3 aquaria (each $48 \times 50 \times 40 \mathrm{~cm}$ ) supplied with running seawater. Illumination was supplied by Philips 36w/w blue type light bulbs suspended over each aquarium. Light intensity was $100 \mu \mathrm{E} \mathrm{m}{ }^{-2} \mathrm{~s}^{-1}$, equivalent to the light level at approximately $15 \mathrm{~m}$ depth on the reef slope (details in Lapid et al. 2004). This light intensity was lower than at the depth where colonies were collected ( 2 to $6 \mathrm{~m}$, see above) due to lighting constraints of the culture facility. Colonies were fed daily with brine shrimp nauplii. Fouling organisms were removed from tank surfaces and from the base of each coral every $3 \mathrm{~d}$. Removal of fouling organisms (algae, sponges, tunicates) from exposed skeletal areas on the corals was difficult, and not all of them were removed, in order to avoid damaging adjacent live coral tissue.

Damage was measured to the nearest millimeter as the surface area of exposed skeleton on each dome- 
shaped coral colony, using a fine flexible ruler made of transparent underwater paper accurate to $1 \mathrm{~mm}$ (after Lapid et al. 2004). The maximal and minimal diameters through the center of the damaged area on each coral were measured, and the area of the ellipse was calculated. Damage was measured every 3 to $4 \mathrm{~d}$ during the first $2 \mathrm{mo}$, and then approximately every $2 \mathrm{wk}$ for $1 \mathrm{yr}$.

The buoyant weight technique was used to assess coral skeletal accretion rate (Jokiel et al. 1978). All colonies were weighed at the start of the experiment and then every $3 \mathrm{mo}$ for approximately $1 \mathrm{yr}$ (after Romano 1990). During weight measurements, each colony was placed in a net suspended from an electronic balance (UWE Electronic Scales) positioned over the experimental aquaria, so that colonies remained continually submersed in seawater. The accuracy of the scale (to $2 \mathrm{~g}$ ) was high compared to increases in coral weight observed over 1 yr (up to $26 \mathrm{~g}$ ). After weighing, all corals were immediately returned to their original locations and orientations in the tanks. They fully expanded during the night after each growth measurement, and did not appear to be stressed by the sampling process. Skeletal accretion rate was expressed as the percent change in buoyant weight relative to initial weight for each colony.

Long-term observations on tentacle length in each coral colony were made approximately every 3 to $4 \mathrm{wk}$ for the duration of the experiment. During the first 2 mo, observations were made every 3 to $4 \mathrm{~d}$; the development of sweeper tentacles during this initial period is reported elsewhere (Lapid et al. 2004). Sweeper tentacles were defined as long tentacles possessing an enlarged tip relative to the stalk, in contrast to feeding tentacles, which were defined as short, tapered tentacles (after Lapid et al. 2004). Random sweeper tentacles were defined as those that appeared at unpredictable locations on the colony, apparently as chance events and not directed toward competitor contact. During each observation, the lengths of the 3 longest tentacles were recorded at 2 locations on each treatment colony: (1) the side facing an adjacent coral, and (2) the opposite side not facing an adjacent coral. On isolated control coral colonies, 2 arbitrary opposing sides were examined for tentacle length. All tentacle measurements were conducted using a fine transparent ruler accurate to $1 \mathrm{~mm}$, as described in Lapid et al. (2004).

A 2-way ANOVA was applied to assess differences in coral weight and tentacle length between treatment and control colonies, with months (time) as a repeated measurement factor. Percentage data were arcsin transformed before analysis. Homogeneity of variance among data-transformed samples was confirmed using the Cochran statistic. Results are presented as means \pm $1 \mathrm{SE}$ except where indicated.

\section{RESULTS}

\section{Tentacle length}

Nine out of 10 experimental colonies of Platygyra daedalea developed sweeper tentacles on the side facing Favites complanata. The effect of competitive contact on tentacle length was significant up to $150 \mathrm{~d}$ following the start of the experiment (Table 1, Fig. 1). There was a significant interaction effect (treatment $x$ time), indicating that the effect of contact treatment on tentacle length varied over time up to $150 \mathrm{~d}$ (Table 1). After this period, tentacle length declined until the end of the experiment at $343 \mathrm{~d}$ (Fig. 1). Maximal tentacle length on the side of $P$. daedaelea colonies facing competitors was $64.3 \pm 17.8 \mathrm{~mm}$, which was longer than the maximum after $150 \mathrm{~d}(44.0 \pm 22 \mathrm{~mm})$, due to amongcolony variation in the time at which sweeper tentacles reached their full development $(157.7 \pm 42.1 \mathrm{~d})$. The longest sweeper tentacle observed was $90 \mathrm{~mm}$ in length, or $15 \times$ longer than normal feeding tentacles at about $6 \mathrm{~mm}$ length (Lapid et al. 2004). In 6 of the 10 experimental colonies of $P$. daedalea, reversion of sweeper tentacles back to normal feeding tentacles was complete by the end of the experiment (Fig. 1A).

In addition, 4 experimental colonies of Platygyra daedalea developed sweeper tentacles on the colony side that did not face competitors. Time to the beginning of development of these tentacles was $113.5 \pm$ $61 \mathrm{~d}$, and time to full development was $186.5 \pm 24 \mathrm{~d}$, slower than for areas facing colonies of Favites complanata (Fig. 1A). The length of these random sweepers at full development was $42.3 \pm 18.6 \mathrm{~mm}$, which differed from their length after $180 \mathrm{~d}(17.3 \pm 16.7 \mathrm{~mm})$ due to among-colony variation in the time to full development (Fig. 1A).

Five of the 10 control colonies of Platygyra daedalea that were isolated from contact with Favites complanata colonies also developed sweeper tentacles at random locations on each colony. Time to the begin-

Table 1. Platygyra daedalea. Two-way repeated measures ANOVA of effects of treatment on tentacle length, with time as the repeated measure. Treatments $(n=2)$ were contact with colonies of the massive stony coral Favites complanata versus no contact. Times were sampling periods up to $150 \mathrm{~d}$ following the start of experimental contact $(n=18$ times, Fig. 1). $\mathrm{n}=10$ colonies of the massive stony coral $P$. daedalea per treatment

\begin{tabular}{|lrrrc|}
\hline Source of variation & df & \multicolumn{1}{c|}{ MS } & \multicolumn{1}{c|}{$F$} & $\mathrm{p}$ \\
\hline Treatment & 1 & 18858.3 & 168.67 & $<0.001$ \\
Time & 17 & 667.8 & 5.97 & $<0.001$ \\
Treatment $\times$ time & 17 & 384.1 & 3.44 & $<0.001$ \\
Error & 324 & 111.8 & & \\
\hline
\end{tabular}




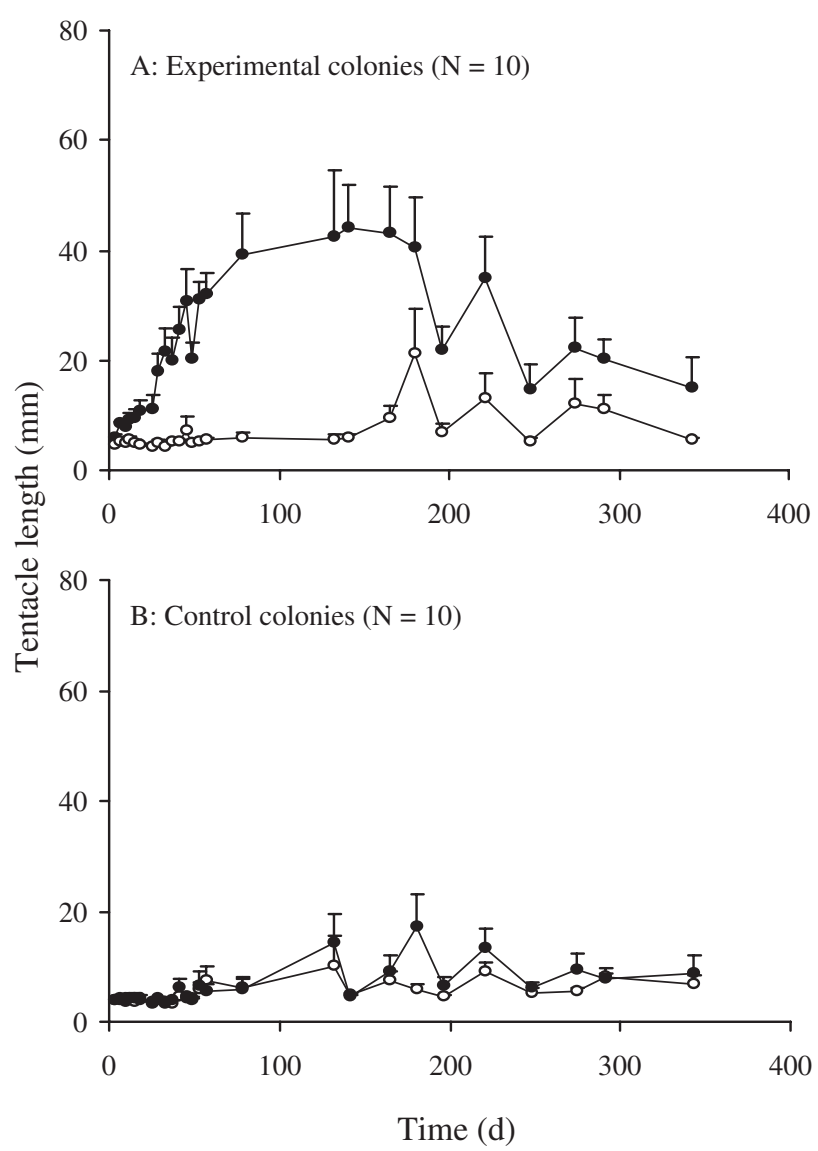

Fig. 1. Platygyra daedalea. Variation in tentacle lengths during $1 \mathrm{yr}$ following the initiation of experimental contact with colonies of the stony coral Favites complanata under laboratory conditions. Shown are means +1 SE. (A) Tentacle lengths on experimental colonies. (๑) Side facing contact with F. complanata; (O) side facing away from contact. (B) Tentacle lengths on control colonies that were not in contact with $F$. complanata. (๑), (O) opposite sides on each colony

ning of development varied greatly $(170 \pm 78 \mathrm{~d})$, and the lengths of these tentacles did not vary significantly over time (Fig. 1B).

Colonies of Platygyra daedalea each developed $28.9 \pm 28.0$ sweeper tentacles on the side facing competitive contact, but only $14.8 \pm 7.4$ random sweeper tentacles in areas not facing contact (see 'Materials and methods' for definition). The number of sweeper tentacles reported for experimental colonies facing competitors is an under-estimate, due to difficulty in counting all of the numerous tentacles before they contracted under the observation light. However, the reported number of random sweeper tentacles that were not facing competitors is exact, because they were fewer and easier to count.

Four colonies of Favites complanata also developed sweeper tentacles: 2 of the control colonies and 2 colonies that were in competition. One of the experimen- tal colonies developed sweeper tentacles approximately 2 mo after the beginning of the experiment, and injured the adjacent colony of Platygyra daedalea, while the second developed sweeper tentacles only at $4 \mathrm{mo}$, after being injured by the contacted $P$. daedalea colony.

\section{Tissue damage}

Nine of the 10 experimental colonies of Favites complanata exhibited tissue damage, which increased significantly on the side of each colony that faced contact with a colony of Platygyra daedalea (Regression analysis on mean values, $\mathrm{r}^{2}=0.96, \mathrm{p}<0.001$, Fig. 2A). One of the $F$. complanata colonies did not suffer tissue damage; instead it caused significantly increasing damage to the adjacent colony of $P$. daedalea (Regression analysis, $\mathrm{r}^{2}=0.98, \mathrm{p}<0.001$, Fig. 2B). No tissue damage was observed on the side of each colony that faced away from other corals.

The time from initiation of competitive contact to the first appearance of bare skeleton was $24 \pm 15.9 \mathrm{~d}$ (Fig. 2A). On some corals, damage was visible as early as $9 \mathrm{~d}$ following the start of contact, while on others it occurred only after $60 \mathrm{~d}$. On 3 colonies of Favites complanata, all of the tissue eventually became damaged, and they died at 260, 307, and $319 \mathrm{~d}$ following initial contact with Platygyra daedalea. Bare skeletal areas on damaged corals were colonized by fouling organisms, and none of the corals regenerated lost tissue during the experiment. By the end of the year, the treatment colonies of $F$. complanata that contacted $P$. daedalea corals had lost $55.4 \pm 29.8 \%$ of their live tissue.

The area of tissue damage on each contacted Favites complanata coral continued to increase throughout the year, even though the long sweeper tentacles on adjacent colonies of Platygyra daedalea reverted to much shorter feeding tentacles after about $170 \mathrm{~d}$ (compare Figs. 1A \& 2A). By the end of the year, the amount of tissue damage on F. complanata colonies varied significantly with the length of sweeper tentacles that had developed on adjacent $P$. daedalea colonies (Regression analysis, $\mathrm{r}^{2}=0.39, \mathrm{p}<0.05$, Fig. 3A). Colonies of $P$. daedalea that produced sweeper tentacles $<40 \mathrm{~mm}$ long caused $<60 \%$ tissue damage on contacted F. complanata colonies. However, sweeper tentacles $>50 \mathrm{~mm}$ long resulted in greater damage of up to $100 \%$ of the tissue on contacted corals (Fig. 3A).

\section{Growth rate}

Colony diameters at the start of the experiment (mean of 2 measurements through the center of each 


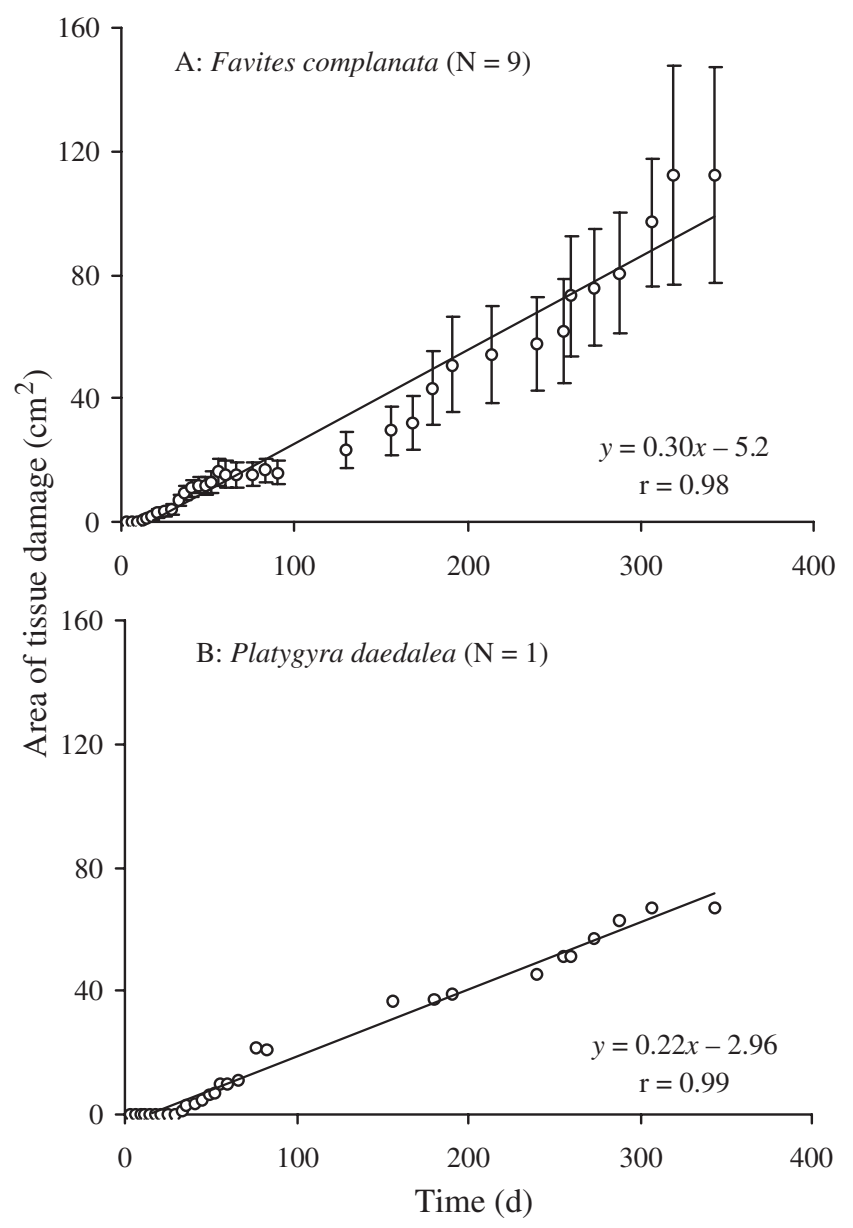

Fig. 2. Patterns of mean tissue damage to stony corals during competition under laboratory conditions. (A) Damage to colonies of Favites complanata by contacted colonies of Platygyra daedalea ( $\pm 1 \mathrm{SE}$ ). (B) Damage to 1 colony of $P$. daedalea by a contacted colony of $F$. complanata

colony) ranged from 6.5 to $12.5 \mathrm{~cm}$ and 5.6 to $10.3 \mathrm{~cm}$, and buoyant weight from 60 to $565 \mathrm{~g}$ and 65 to $320 \mathrm{~g}$ for Platygyra daedalea and Favites complanata colonies respectively. At the start of the experiment, experimental and control colonies of $P$. daedalea did not differ significantly in buoyant weight $(t$-test, $\mathrm{df}=9$, $t=0.9, \mathrm{p}=0.18$ ). Experimental colonies of $F$. complanata were significantly heavier than were control colonies ( $t$-test, $\mathrm{df}=9, t=1.73, \mathrm{p}<0.02)$.

Colonies of both species exhibited slow rates of skeletal accretion that averaged about 7 to $12 \%$ weight increase per year (Fig. 4). Skeletal growth also varied widely among individual colonies of Platygyra daedalea (experimental colonies $=2.65 \%$ to $23 \%$, control colonies $=0.9 \%$ to $27.3 \%$ ), and of Favites complanata (experimental colonies $=-3.07 \%$ to $15.4 \%$, control colonies $=-8.6 \%$ to $22.3 \%$ ) within each treatment. Percent increases in buoyant weight did not depend on experimental treatment in either species (P. daedalea: ANOVA, $F_{(1,18)}=0.026, \mathrm{p}=0.87$, Fig. $4 \mathrm{~A}_{\text {; }}$ F. complanata: ANOVA, $F_{(1,18)}=0.006, \mathrm{p}=0.90$, Fig. 4B). Fouling organisms that bored into the exposed skeletons of the corals (see 'Materials and methods') may have caused the negative skeletal growth (weight loss) observed in some $F$. complanata colonies (above and Fig. 3B).

The weight change of contacted Favites complanata corals varied significantly with their tissue damage over 1 yr (Regression analysis, $\mathrm{r}^{2}=0.42, \mathrm{p}<0.05$, Fig. 3B). Corals with $<60 \%$ tissue damage varied widely in their skeletal growth, and grew up to $15.4 \%$
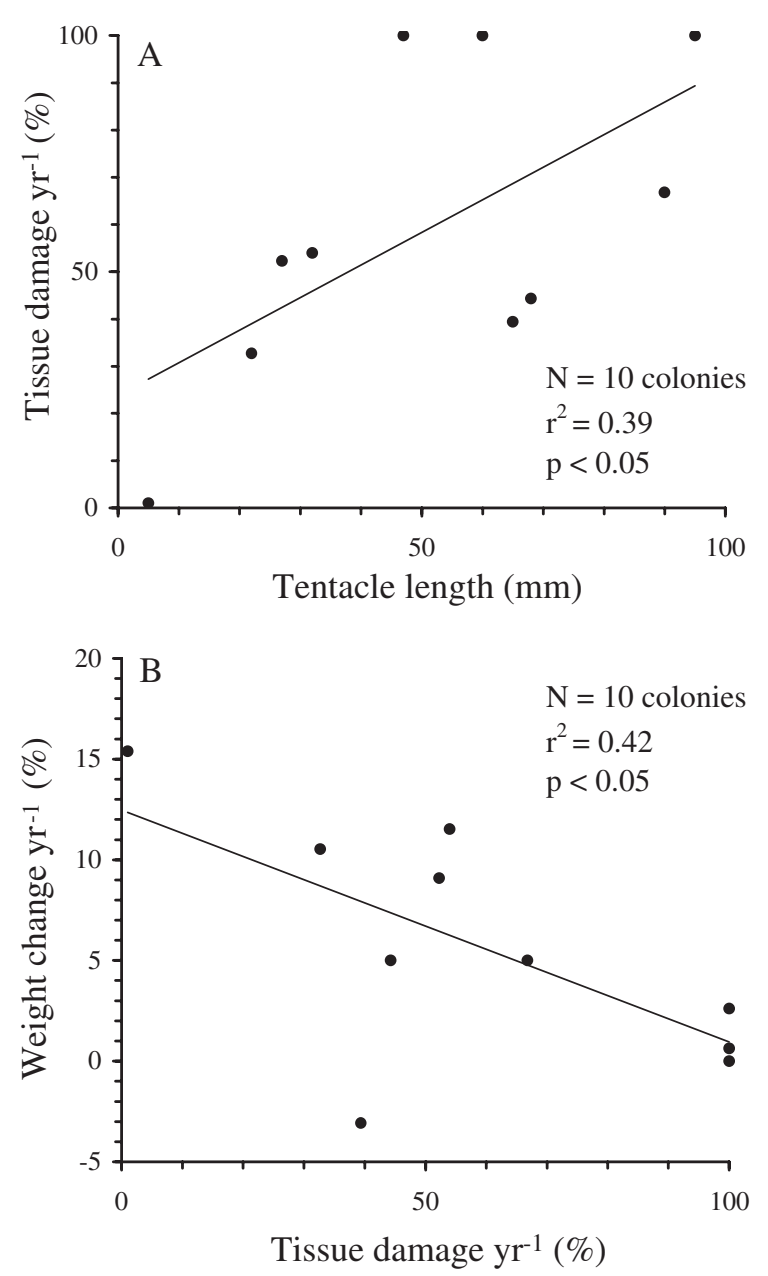

Fig. 3. Favites complanata. Variation in correlates of tissue damage after $1 \mathrm{yr}$ of contact with the stony coral Platygyra daedalea under laboratory conditions. (A) Variation in percent tissue damage with the tentacle length of adjacent colonies of $P$. daedalea. Tentacle lengths represent means of the 3 longest tentacles measured on each colony at full sweeper tentacle development. (B) Variation in rate of skeletal accretion (\% buoyant weight change after 1 yr) with extent of tissue damage ( $\%$ tissue damage after $1 \mathrm{yr}$ ) 


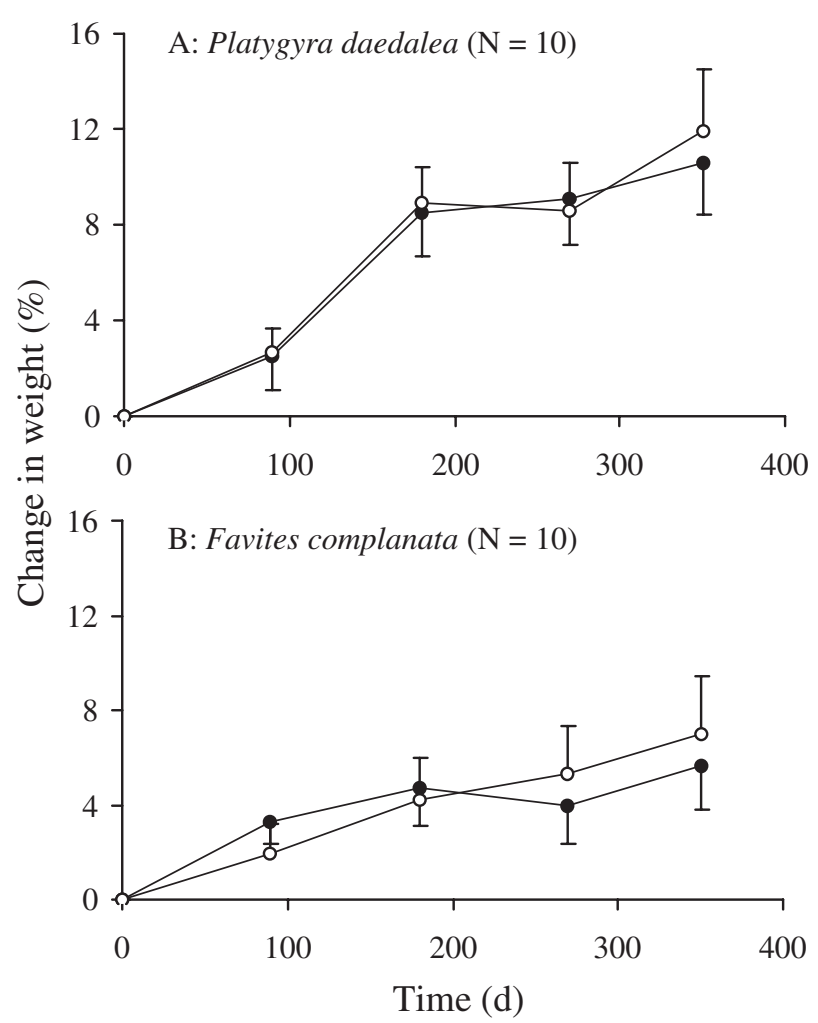

Fig. 4. Skeletal growth rates of stony corals during competition under laboratory conditions. (•) Colonies in contact with competitors (mean - SE); (O) colonies that were isolated from contact (mean $+\mathrm{SE})$. Skeletal growth rate is expressed as \% change in buoyant weight from initial weight. (A) Platygyra daedalea (B) Favites complanata

in weight, while those with $>60 \%$ damage grew little if at all (Fig. 3B). One coral that suffered about $40 \%$ tissue damage lost weight, possibly due to the effect of boring organisms in the exposed coral skeleton (see above and Fig. 3B). The skeletal accretion rate of dominant Platygyra daedalea colonies did not depend on the length or number of sweeper tentacles they developed, or the amount of tissue damage they inflicted on adjacent colonies of $F$. complanata over the year (Regression analyses, $\mathrm{r}^{2}=0.43,0.39$, and 0.19 , and $\mathrm{p}=$ $0.06,0.05$, and 0.71 respectively).

\section{DISCUSSION}

We document here massive long-term damage unilaterally inflicted on most colonies of an inferior coral competitor by brain corals in a year-long laboratory experiment. These results show that, under laboratory conditions with little spatial or temporal variation, long-term 1-way outcomes of interspecific competition can develop among stony corals.
Reversals in competitive dominance may occur due to the use of aggressive mechanisms with different temporal scales such as mesenterial filaments versus sweeper tentacles (Wellington 1980, Chornesky 1989), or due to seasonally-changing environmental conditions or temporal variation in colony size or encounter angle (Buss 1980, Chornesky 1989). The clear lack of reversal in competitive dominance observed in the present laboratory study may be explained in part by the stable conditions of light, water flow and food availability that were provided throughout the year, and by the absence of disturbing mobile organisms (Bak et al. 1982). However, our extensive field survey also revealed mainly unilateral damage to Favites spp. colonies by those of Platygyra daedalea on Red Sea coral reefs (Lapid et al. 2004), so our laboratory data on unilateral outcomes have relevance to the natural setting of these corals. We also observed here that individuals of $F$. complanata developed sweeper tentacles, and that one of them injured an adjacent $P$. daedalea colony. The $F$. complanata colonies that developed sweeper tentacles in our study did not exhibit obvious differences from those that did not, although we did not examine genetic variation among these colonies.

In contrast to previous studies (Romano 1990, Tanner 1997), we did not observe clear differences between control and competitive contact treatments in terms of coral skeletal growth. Tanner's (1997) study was conducted in the field, and resulted in a significant decrease in the planar area of colonies of the branching corals Acropora hyacintus and Pocillopora damicornis during competition with other species, in comparison to control colonies growing alone. Romano (1990) also conducted field studies and used buoyant weight to show that the coral Cyphastrea ocellina grew significantly faster when alone than when placed in contact with branches of the dominant competitor $P$. damicornis. Our laboratory growth experiment may have produced negative results either because: (1) flaws in the design prevented detection of skeletal growth responses to the treatments, or (2) the experiment was well-designed and the treatments truly did not affect coral skeletal accretion (Browman 1999). Both processes may have operated in our study. Our work was conducted under laboratory conditions that may have hindered detection of skeletal growth differences, in contrast to the previous studies conducted under field conditions (Romano 1990, Tanner 1997). Our experimental lighting system provided the equivalent of PAR at $15 \mathrm{~m}$ depth on the coral reef, which was deeper than the collection depth of the organisms we used (see 'Materials and methods'), but within the natural depth range of both coral species (Sheppard \& Sheppard 1991). The consequently slow skeletal accre- 
tion rates of our corals (Fig. 4) may have been insufficient to detect effects of the competition treatments. Also, fouling organisms may have bored into and eroded the coral skeletons, causing weight gain or loss and augmenting among-colony variation in skeletal growth (see 'Results'). Variation in skeletal growth among the control colonies that did not contact competitors (Fig. 4) may have been caused by in part by the effects of these fouling organisms, since their detached coral bases were exposed to colonization. Our electronic scale was accurate only to $2 \mathrm{~g}$ but some corals experienced weight increases of up to $26 \mathrm{~g}$, so scale accuracy is unlikely to have influenced the results. Finally, due to laboratory space constraints, our sample sizes were small. Coral skeletal growth rates are known to vary widely in nature due to a many factors including genetic variation among colonies (Tomascik 1990) and biological interactions such as bioerosion (Glynn 1997) and parasitism of colonies by epibionts (Simon-Blecher \& Achituv 1997, Yap \& Molina 2003). Our experimental design may not have been strong enough to detect competition effects over these confounding factors.

Variation in skeletal accretion among the experimental Favites complanata corals appeared to relate in part to the lengths of sweeper tentacles developed by adjacent Platygyra daedalea colonies, and the amount of tissue damage they subsequently inflicted (Fig. 3). In other species of corals and sea anemones, competitive ability is known to vary widely among individuals and to cause substantial differences in opponent survival and growth (Brace 1981, Ayre 1982, Purcell \& Kitting 1982, Rinkevich \& Loya 1983a, Chadwick-Furman \& Rinkevich 1994). The amount of competitive damage inflicted on each coral thus appeared to influence its skeletal growth rate (Fig. 3). We conclude that high levels of individual variation combined with the methodological constraints of our laboratory study caused some of our negative results, and should be taken into account in the design of future experiments.

The observed lack of skeletal growth variation among dominant Platygyra daedalea colonies with either the number or length of sweeper tentacles they developed, or the amount of damage they caused to adjacent corals (see 'Results') indicates that they did not experience costs to skeletal accretion from this type of competitive treatment. This effect is in contrast to clear variation in skeletal growth of the subordinate coral Favites complanata with the amount of competitive damage received (Fig. 3B). Some corals are known to redirect skeletal growth and/or reduce sexual reproductive output rather than reduce growth rate in response to competition (Rinkevich \& Loya 1983a, 1985, Romano 1990, Chadwick 1991, ChadwickFurman \& Rinkevich 1994). Romano (1990) observed that the skeletal accretion rate of dominant Pocillopora damicornis branches was not affected by contact with dead or live colonies of the subordinate competing coral Cyphastrea ocellina. Thus, dominant coral competitors do not always incur a cost in skeletal growth, indicating that sweeper tentacle development may not be particularly costly in terms of this parameter for corals. The possibly low cost of sweeper tentacle development may allow corals to produce them occasionally at random, in the absence of apparent stimuli (Lapid et al. 2004, Fig. 1).

The energetic expenditures involved in producing sweeper tentacles or any other competitive structures have not been quantified in anthozoans. Any energetic cost to the dominant coral Platygyra daedalea also may have been obscured in our experiment by energy gained from the consumption and digestion of Favites complanata tissue by $P$. daedalea through eversion of mesenterial filaments by the brain corals. A preliminary experiment revealed that organic matter potentially is transferred to the aggressive coral via extracoelenteric digestion of subordinate coral tissues (Lapid 2004). Thus, mesenterial eversion and other types of aggression by coral competitors potentially could result in energetic gain rather than cost, as suggested by Rinkevich \& Loya (1983b) and Romano (1990).

We observed that sweeper tentacles developed mainly near areas of contact with competing corals, similar to observations in previous studies (Wellington 1980, Hidaka \& Yamazato 1984, Chornesky 1989). However, individuals of both species here also produced sweeper tentacles at random locations on the colony, under both laboratory (Fig. 1B) and field conditions (Lapid et al. 2004). About 50\% of isolated control colonies of Platygyra daedalea and $25 \%$ of those of Favites complanata developed sweeper tentacles at random spatial and temporal scales throughout our 1 yr period of observation (Fig. 1). These results indicate that some corals may randomly produce sweeper tentacles to serve as probes which scan the surrounding environment and detect the advance of neighboring corals (Lapid et al. 2004).

The sweeper tentacles observed here reverted back to normal feeding tentacles after causing extensive damage to competitors, as shown in other studies (Wellington 1980, Chornesky 1989), and also after random development when no competitors were detected (Fig. 1). Regression of Platygyra daedalea sweeper tentacles back to normal ones (Fig. 1A) may have occurred in response to cessation of tentacle contact after the tissue area on the colonies of Favites complanata was greatly reduced (Fig. 2A). Randomlydeveloped sweeper tentacles also regressed eventually (Fig. 1), possibly because they did not contact any 
competitor tissues. Thus, our corals likely did not habituate to competitor contact as observed by Purcell \& Kitting (1982) for fighting sea anemones, since tissue contact was not maintained in our experiment. Damage to the $F$. complanata colonies continued to increase even after the elongated $P$. daedalea tentacles shrank (compare Figs. 1A \& 2A), consistent with the findings of Bak \& Steward-Van Es (1980) and Cumming (2002) that coral lesions above a certain size usually are not regenerated. The fouling organisms that colonized the bare coral skeletons in our experiment may have prevented coral tissue from regenerating, and expanded the zone of damage.

In conclusion, this long-term laboratory experiment revealed non-reversible outcomes of coral competition, and the production and regression of elongated sweeper tentacles at both random and directed locations on stony coral colonies. These observations have relevance to the natural setting of these corals, as they have also been observed on coral reefs in the field (Lapid et al. 2004). Our observations demonstrate the dynamic and complex nature of coral competitive interactions, with both defensive (pre-emptive) and aggressive functions being served by a single organ, in this case the sweeper tentacles of brain corals.

Acknowledgements. We thank G. Ayalon and A. Levi, the former and current head aquarists respectively, of the Underwater Observatory Marine Park in Eilat, for use of their facilities and sea water system. We also thank S. Einbinder for helping with identification of the corals, and B. George and other students at the IUI who assisted with nocturnal measurements. Special thanks to B. Karpestam, and to S. Pearce for technical assistance. Funding was provided by a grant to N. E. C. from Bar Ilan University. This work was submitted in partial fulfillment of the requirements for the M.Sc. degree to E. D. Lapid at Bar Ilan University.

\section{LITERATURE CITED}

Ayre DJ (1982) Inter-genotype aggression in the solitary sea anemone Actinia tenebrosa. Mar Biol 68:199-205

Bak RPM, Steward-Van Es Y (1980) Regeneration of superficial damage in the scleractinian corals Agaricia agaricites F. purpurea and Porites astreoides. Bull Mar Sci 30:883-88

Bak RPM, Termaat RM, Dekker R (1982) Complexity of coral interactions: influence of time, location of interaction and epifauna. Mar Biol 69:215-222

Bigger $\mathrm{CH}$ (1988) The role of nematocysts in anthozoan aggression. In: Hessinger D, Lenhoff $\mathrm{H}$ (eds) The biology of nematocysts. Academic Press, New York, p 295-308

Brace RC (1981) Intraspecific aggression in the colour morphs of the anemone Phymactis clematis from Chile. Mar Biol 64:85-93

Browman HL (1999) Negative results. Mar Ecol Prog Ser 191: 301-309

Buss LW (1980) Competitive intransitivity and size-frequency distributions of interacting populations. Proc Nat Acad Sci
USA 77:5355-5359

Chadwick NE (1988) Competition and locomotion in a freeliving fungiid coral. J Exp Mar Biol Ecol 123:189-200

Chadwick NE (1991) Spatial distribution and the effects of competition on some temperate Scleractinia and Corallimorpharia. Mar Ecol Prog Ser 70:39-48

Chadwick-Furman N, Rinkevich B (1994) A complex allorecognition system in a reef-building coral: delayed responses, reversals and nontransitive hierarchies. Coral Reefs 13:57-63

Chornesky EA (1989) Repeated reversals during spatial competition between corals. Ecology 70:843-855

Cumming (2002) Tissue injury predicts colony decline in reefbuilding corals. Mar Ecol Prog Ser 242:131-141

Davies PS (1989) Short-term growth measurements of corals using accurate buoyant weighing technique. Mar Biol 101: 389-395

Glynn PW (1997) Bioerosion and coral-reef growth: a dynamic balance. In: Birkeland C (ed) Life and death of coral reefs. Chapman \& Hall, New York, p 68-95

Guzman HM, Cortes J (1989) Growth rates of eight species of scleractinian corals in the eastern Pacific (Costa Rica). Bull Mar Sci 44:1186-1194

Hidaka M, Yamazato K (1984) Intraspecific interactions in a scleractinian coral, Galaxea fascicularis: induced formation of sweeper tentacles. Coral Reefs 3:77-85

Huston M (1985) Variation in coral growth rates with depth at Discovery Bay, Jamaica. Coral Reefs 4:19-25

Jackson JBC (1977) Competition on marine hard substrata: the adaptive significance of solitary and colonial strategies. Am Nat 111:743-767

Jokiel PL, Maragos JE, Franzisket L (1978) Coral growth: buoyant weight technique. In: Stoddart DR, Johannes RE (eds) Coral reefs: research methods. UNESCO, p 529-541

Klein R, Loya Y (1991) Skeletal growth and density patterns of two Porites corals from the Gulf of Eilat, Red Sea. Mar Ecol Prog Ser 77:253-259

Lamberts AE (1974) Measurement of alizarin deposited by coral. Proc 2nd Int Coral Reef Symp 2:241-244

Lang JC, Chornesky EA (1990) Competition between scleractinian reef corals: a review of mechanisms and effects. In: Dubinsky Z (ed) Coral reefs. Ecosystems of the world. Vol. 25. Elsevier, Amsterdam, p 209-252

Lapid E (2004) Aspects of competition and aggression in the brain coral Platygyra daedalea. MSc thesis, Bar Ilan University, Ramat Gan, Israel

Lapid ED, Wielgus J, Chadwick-Furman NE (2004) Sweeper tentacles of the brain coral Platygyra daedalea: induced development and effect on competitors. Mar Ecol Prog Ser 282:161-171

Meesters EH, Wesseling I, Bak RPM (1996) Partial mortality in three species of reef-building corals and the relation with colony morphology. Bull Mar Sci 58:838-852

Oliver JK (1983) Bathymetric adaptations or reef-building corals at Davies Reef, Great Barrier Reef, Australia. 1. Long-term growth responses of Acropora formosa (Dana 1846). J Exp Mar Biol Ecol 73:11-35

Purcell JE, Kitting CL (1982) Intraspecific aggression and population distributions of the sea anemone Metridium senile. Biol Bull 162:345-359

Rinkevich B (1996) Do reproduction and regeneration in damaged corals compete for energy allocation? Mar Ecol Prog Ser 143:297-302

Rinkevich B, Loya Y (1983a) Intraspecific competitive networks in the Red Sea coral Stylophora pistillata. Coral Reefs 1:161-172

Rinkevich B, Loya Y (1983b) Oriented translocation of energy 
in grafted reef corals. Coral Reefs 1:243-247

Rinkevich B, Loya Y (1985) Intraspecific competition in a reef coral: effects on growth and reproduction. Oecologia 66: 100-105

Rinkevich B, Loya Y (1989) Reproduction in regenerating colonies of the coral Stylophora pistillata. In: Spanier E, Steinberger Y, Luria $M$ (eds) Environmental quality. ISEEQS, Jerusalem, p 257-265

Romano SL (1990) Long-term effects of interspecific aggression on growth of the reef-building corals Cyphastrea ocellina (Dana) and Pocillopora damicornis (Linnaeus). J Exp Mar Biol Ecol 140:135-146

Sebens KP (1982) Competition for space: growth rate, reproductive output, and escape in size. Am Nat 120:189-197

Sheppard CRC, Sheppard ALS (1991) Corals and coral communities of Arabia. Fauna Saudi Arabia 12:1-165

Simon-Blecher N, Achituv Y (1997) Relationship between the coral pit crab Cryptochirus coralliodytes Heller and its host coral. J Exp Mar Biol Ecol 215:93-102

Tanner JE (1997) Interspecific competition reduces fitness in scleractinian corals. J Exp Mar Biol Ecol 214:19-34

Thomason JC, Brown BE (1986) The cnidom: an index of aggressively proficiency in scleractinian corals. Coral Reefs 5:93-101

Editorial responsibility: Otto Kinne (Editor-in-Chief), Oldendorf/Luhe, Germany
Tomascik T (1990) Growth rates of two morphotypes of Montastrea annularis along a eutrophication gradient, Barbados, W.I. Mar Poll Bull 21:376-381

Vago R, Vago E, Achituv Y, Ben-Zion M, Dubinsky Z (1994) A non-destructive method for monitoring coral growth affected by anthropogenic and natural long term changes. Bull Mar Sci 55:126-132

Ward S (1995) The effect of damage on the growth, reproduction and storage of lipids in the scleractinian coral Pocillopora damicornis (Linnaeus). J Exp Mar Biol Ecol 187: 193-206

Wellington GM (1980) Reversal of digestive interactions between Pacific reef corals: mediation by sweeper tentacles. Oecologia 47:340-344

Williams RB (1991) Acrorhagi, catch tentacles and sweeper tentacles: a synopsis of aggression of actiniarian and scleractinian Cnidaria. Hydrobiologia 216/217:539-545

Yap HT, Alino PM, Gomez ED (1992) Trends in growth and mortality of three coral species (Anthozoa: Scleractinia), including effects of transplantation. Mar Ecol Prog Ser 83: 91-101

Yap HT, Molina RA (2003) Comparison of coral growth and survival under enclosed, semi-natural conditions and in the field. Mar Poll Bull 46:858-864

Submitted: March 1, 2005; Accepted: December 19, 2005 Proofs received from author(s): March 21, 2006 